\title{
The Use of Participatory Action Research within Education-Benefits to Stakeholders
}

\author{
Steven Jacobs ${ }^{1, *}$ \\ ${ }^{1}$ George Brown College, 51 Dockside Ave, Toronto, Ontario M5T 2T9, Canada \\ *Correspondence: George Brown College, 51 Dockside Ave, Toronto, Ontario M5T 2T9, Canada. E-mail: \\ sjacobs@uvic.ca
}

Received: May 12, 2016

Accepted: June 1, 2016 Online Published: June 3, 2016

doi:10.5430/wje.v6n3p48

URL: http://dx.doi.org/10.5430/wje.v6n3p48

\begin{abstract}
This paper offers a brief history and the characteristics of the research methodology known as Participatory Action Research (PAR). This paper also states how PAR can be utilized within an educational environment and describes the benefits to all stakeholders such as teachers and students when they are involved in a research project using PAR as the research methodology.
\end{abstract}

Keywords: participatory action research; education

\section{Introduction}

Participatory Action Research (PAR) originated in the late 1960s to address issues with disadvantaged members of society (Calhoun \& Karaganis, 2001; Fals-Borda, 2001; Kidd \& Kral, 2005; Susman \& Evered, 1978; Whyte, 1991). Since that time, PAR has been used within various fields and disciplines. One field which has utilized a PAR methodology is the field of education. The purpose of this paper is to examine the use of PAR within education in order to articulate the benefits to students, teachers, and other stakeholders when they engage in a PAR project within their educational institution. This paper will begin by offering an explanation/definition of PAR. This paper will then include a brief history of PAR as a research methodology, and the final section of this paper will articulate the use and benefit to stakeholders when adopting a PAR project within educational institutions.

\section{Literature Review}

Participatory action research (PAR) is a thread of action research (Savin-Baden \& Wimpenny, 2007; Young, 2013), as not all action research is collaborative (Bergold \& Thomas, 2012). Action research is a research methodology which is often associated with the work of Kurt Lewin in the 1940s (Greenwood \& Levin, 1998; Gustavsen, 2001; Reason \& Bradbury, 2001; Savin-Baden \& Wimpenny, 2007; Young). And although Lewin did emphasize the importance of collaboration in some of the research processes (Pine, 2009), one of the central tenets of PAR is its participatory nature to include all stakeholders in all aspects of the research process (Brydon-Miller, Kral, Maguire, Noffke, \& Sabhlok, 2011; Cook, 2012; Streubert, \& Carpenter, 2011; Young). This participatory nature of PAR embodies a democratic approach to research in which participants work collaboratively in the co-generation of new knowledge to address a specific issue or problem (Bergold \& Thomas; Koch, \& Kralik, 2006; Reason \& Bradbury, 2001; Streubert, \& Carpenter; Young). A research project which utilizes a PAR methodology rejects traditional positivist research paradigms and challenges traditional hierarchies between the researcher and those being researched (Borg, Karisson, Kim, \& McCormack, 2012; Kindon, Pain, \& Kesby, 2007; MacDonald, 2003; Ozanne \& Saatcioglu, 2008).

MacDonald (2003) stated this hierarchy is present within a traditional positivist research approach as positivist epistemology holds the researcher as the sole producer of knowledge, operating in an autocratic relationship, and that one single reality exists which can be observed measured. Contrary to this, PAR postulates that the researcher/observer not only impacts the phenomenon being researched (as they bring their values to the research process), but also that there are multiple realities present in the data due to the collaborative and social aspect of knowledge creation associated with PAR (Baum, MacDougall, \& Smith, 2006; Ozanne, \& Saatcioglu; Streck 2014). 
Central to this challenge of traditional positivist research methodology is also the fact that a PAR project holds that research is conducted with participants, rather than on participants (Herr, \& Anderson, 2015; Heron \& Reason, 2001; Kindon, Pain, \& Kesby; Savin-Baden \& Wimpenny). Within an educational institution, this would propose research is to be conducted with students, rather than on students.

\section{Defining Participatory Action Research}

Certainly there is more than one definition of PAR in the literature; however, I find the definition by Reason and Bradbury (2008) one which encompasses many of the characteristics of PAR. They define PAR as a process which develops practical knowing while pursuing worthwhile human purposes (Reason \& Bradbury). Participatory action research combines theory and practice, action and reflection with the participation of stakeholders who seek practical solutions to concerns and issues, allowing the flourishing of those stakeholders and their communities as a result of the research process (Reason \& Bradbury). Further to this definition, Baldwin (2012) reminds us that PAR is transformative rather than simply informative. This premise also refers to the fact that PAR is based on the assumption that humans are social animals (Hall, 1975), and that knowledge is socially created through a constructivist approach (Baldwin; Hall, 1975; Savin-Baden \& Wimpenny, 2007). Streubert and Carpenter (2001) state that using one definition for PAR is difficult, and it is the assumptions such as collaboration, participation, non-hierarchical, and a democratic approach inherent within action research and PAR which can better assist the nurse researcher in determining if PAR is a useful approach to their area of study.

The definitions and assumptions stated above speak to the epistemology of PAR which believes that knowledge is rooted in the experiences and lives of individuals and that knowledge is created through collaboration between the researcher and co-researchers (Bergold, \& Thomas, 2012; Borg, Karisson, Kim \& McCormack, 2012; Minkler, 2000; Savin-Baden \& Wimpenny, 2007). It further speaks to the constructivist nature of PAR knowledge and understanding, which is based on learning and knowing as communal acts and how humans are social animals (Baldwin, 2012 Hall, 1975; Pine, 2009; Savin-Baden \& Wimpenny, 2007). Within an educational environment, Dewey (1997) referred to this when he spoke of the fact that often the teacher has more to learn than to teach. One of the ways to facilitate this is through a more collaborative, democratizing learning environment, which would benefit both teachers and students.

\section{Participatory Action Research Theory and Practice}

Participatory Action Research has drawn upon a number of theories such as pragmatism, the practice of democracy, constructionist theory, and feminist inquiry (Reason \& Bradbury, 2001). With respect to pragmatism, Dewey (1938) stated that any set of practices is dogmatic when not based upon critical reflection of its own underlying principles. Both participatory action research and education holds that reflection is important (Palmer, 2007; Pine, 2009; Reason $\&$ Bradbury, 2001). Freire (2005) stated that an attempt to liberate someone without their reflective participation is akin to treating them as 'objects', and Dewey (1938) believed the control of individual actions are effected by the entire situation in which one is involved in, which one shares, and in which one is co-operative or interacting with others. This can only be achieved through reflection. As educators, we need to remind ourselves that our job is to constantly put on a new lens to view the world (Palmer). Only by viewing the world through this new lens (by engaging students in a research project from start to finish using PAR) can we see things that otherwise remain invisible to us (Palmer). And this can only be achieved by engaging in true reflection of all our actions and communications as educators, which PAR offers. Reflection and the opportunity to work with students on a research project using PAR methodology also follows Dewey's (1997) belief that the teacher has more to learn than to teach, as a PAR project respects the voice and knowledge of all research participants and allows knowledge to be constructed through group collaboration and participation.

Participatory action research is also a democratic research process (Greenwood \& Levin, 1998; Koch \& Kralik, 2006; Reason \& Bradbury, 2001; Streubert, \& Carpenter, 2011). Participatory action research places a strong value on participant participation and democracy as everyone involved takes some responsibility during the research process (Greenwood \& Levin). Further, the democratic aspect of PAR ensures that all stakeholders (students and teachers) act as co-researchers (Greenwood \& Levin). Koch \& Kralik discuss how PAR is a democratic process to create new knowledge. They also state that researchers work collaboratively with participants as they co-generate knowledge which addresses a problem (Koch \& Kralik). Because of this relationship and environment, PAR allows embraces a democratic and non-hierarchical relationship between researcher and participant(s).

Participatory action research also has a strong constructionist component to it with respect to epistemology. 
According to Baldwin (2012) PAR is constructionist and knowledge is socially constructed. Savin-Baden and Wimpenny (2007) agree, stating that within PAR, knowledge is constructed by the persons involved in the research process, it is a social enterprise. All stakeholders working together on a PAR project in a non-hierarchical, democratic environment create, generate, and construct knowledge, discovery, and understanding together, resulting in rich explanations and interpretations.

Dahl (2014) conducted a PAR study to bring about change in student/teachers' relationship which is often described as teacher dominated and authoritarian. Participants both (students and teachers) talked about feeling empowered as a result of the project. This led to increased participatory teaching practices for the teachers and a willingness to continue to develop and explore their practice beyond the PAR initiative (Dahl). These findings are consistent with Feldman (2007) who found participants become aware of their resources and abilities to increase their self-confidence and problem-solving abilities when working on a PAR project.

Bywater (2014) conducted a PAR project in her college with students analyzing how their everyday activities may exacerbate poor human and environmental health. From a pedagogical perspective, Bywater found that a PAR project encourages participants to acquire knowledge, skills and opportunities to solve problems. Further, the project gave students an opportunity to develop investigational and evaluative knowledge. Finally, consistent with PAR, the professor in this project acted as research facilitator, which resulted in students designing and carrying out every aspect of the project which increases students' investment, engagement and ownership in knowledge production (Bywater). While these are only a few examples of students participating in a PAR project, they do demonstrate the benefits to students and teachers when working together.

\section{Participatory Action Research \& Feminist Inquiry}

With respect to power, another huge influence on PAR has been feminist inquiry. Many authors discuss the influence feminist inquiry has had on PAR (Herr \& Anderson 2015; Greenwood \& Levin, 1998; Pine, 2009; Reason \& Bradbury, 2001). From a postmodern perspective, feminism is seen as a powerful intellectual influence on action research and PAR due to a shared epistemology that knowledge and reality is subject to constant change, and that reality is fluid, local, and constructed in the mind (Pine). Feminist researchers focus on power, the relationship between the researcher and research participants, the connections between knowledge and feelings, and the construction of knowledge (Pine). According to Tarnas (1991) the feminist perspective has offered a critical analysis of cultural and intellectual assumptions within all academic disciplines. With respect to PAR, Bryden-Miller, Maguire, and McIntyre (2004) assert that research (and knowledge creation) cannot be transformative without an understanding of feminist inquiry and the tenets of same. Pavlish and Pharris (2012) state that applying a feminist lens to participatory action research is necessary as it allows researchers to attend intentionally to the perspectives and diversity of voices within the research process. Lastly, Greenwood and Levin state that feminism was responsible for a resurgence of PAR.

The inclusion of feminist inquiry within participatory action research was led by Patricia Maguire who voiced a feminist approach to PAR in her influential book Doing Participatory Research: A Feminist Approach (Young, 2013). It would not be possible to summarize Maguire's entire book and work within this paper, however, some points are worthy of exploration. Although Maguire (1987) uses the term participatory research (PR) rather than participatory action research, many of the characteristics are the same, and she states that the core issue for PR is power. Initiating a PAR project with feminist principles is truly a collaborative enterprise. As Maguire states, PR begins with the premise that knowledge has become the single most important basis for power and control, and that ordinary people are rarely considered knowledgeable. Further, Maguire states PR epistemologically holds the premise that each participant knows some things, but no one know everything. This philosophy refers to the previous point by Pine (2009) who states knowledge is power. Gaventa and Cornwall (2001) also state that "power and knowledge are intertwined" (p. 70), but also point out that power can be a positive attribute as in the power to act. They further state that one of the purposes of PAR is to empower participants "through the construction of their own knowledge" (p. 73). This type of approach bodes well for a PAR project involving teachers and students as it debunks what Freire (2005) refers to as the 'banking' concept of education and advocates for a more participatory learning environment. Finally as previously stated, Downes and Groundwater-Smith (1999) believe it is an ethical consideration to 'hear' students as they have a right to be heard and listened too. They as ask: who knows better what it is like to be a student than students themselves (Downes \& Groundwater-Smith)? 


\section{Participatory Action Research and Education}

The use of participatory action research within the field of education began in the 1940s and 1950s at the Teachers College in Columbia University by Stephen Corey and colleagues. Corey called for collaborative research as an alternative to current research paradigms in schools which were based on positivist approaches (Pine, 2009). Corey (1953) believed that traditional research approaches would not influence American education in useful ways and/or be of benefit to all stakeholders-teachers, administrators, students, parents, and university faculty. Corey advocated for teachers to be equal participants in collaborative action research and stated they need to play an active role in research study design, data collection, and data interpretation. Others advanced and continued Corey's work and beliefs. Schaefer (1967) advocated for schools to become collaborative centres of inquiry rather than simply centres of information dissemination.

During the late 1950s and 1960s, the use of action research declined as it was not viewed as legitimate research (Pine, 2009). Criticisms of action research included the fact that it did not utilize quantitative methods of control, was not statistically sophisticated, was research conducted by teachers who were amateur researchers', and was not as rigorous as experimental science (Hodgkinson, 1957; Pine). Since the 1970s these criticisms have been challenged and PAR as a research approach gained in use and legitimacy. One of the leaders of this resurgence in PAR (within education) in the 1970s was Paulo Freire. Freire (2005) studied oppressive educational environments in Brazil and introduced such concepts as dehumanization, the difference between subjects versus objects in research, co-intentional education, and the banking concept of education. Many of the principles of PAR resemble Freire's thoughts on equality, partnerships, control, and student and instructor as teachers in educational environments. As Freire stated, education is not carried out by one for another, or by one about another, but by one with another. As already stated, PAR research is not research conducted on another, but with another. This type of collaboration in research allows all stakeholders to reflect upon each other's thinking and become "jointly educated" (Freire, p. 109).

Examining education further, Downes and Groundwater-Smith (1999) argues that it is an ethical issue to 'hear' students, and believes that students have a right to be heard and listened too (John, 1996). This is so because it is the students' future which is at state, more so than faculties' and other stakeholders (Downes \& Groundwater-Smith). Downes and Groundwater-Smith also state that the absence of young people in research initiatives is similar to the absence of women in traditional patriarchal research, who were silenced and patronised. Possibly this is another reason why feminism has been so influential to participatory action research? Freire (2005) discusses this when he stated how the oppressor wishes to silence the oppressed in order to keep control over them. This has been one of the criticisms of traditional positivist research-that it controls and silences those who have an interest or are affected by the research.

Brydon-Miller, and Maguire (2009) contend that schools are the ideal site for social change efforts and that PAR is central to that struggle. Hooks (1994) agrees, stating that the classroom is a radical space of possibility. Pine (2009) states single schools are "research goldmines" (p.10) in terms of variety and richness of data, important questions, and number of potential researchers. Education institutions are also workplaces, and schools as workplaces are extraordinarily powerful in influencing student learning and teacher behaviour (Pine). Further, each school has its own culture, history, norms, values, and beliefs (Pine). School culture affects the behaviour and achievements of its members. A school culture based on hierarchy and power inequities fosters domination and control. A school culture based on PAR tenets such as participation, collaboration and non-hierarchical relationships, fosters increased growth and discovery. Although thus far, I have spoken about the benefits when one engages in a PAR project, this is not to suggest that a PAR initiative is a one-time isolated initiative. As Pine states, PAR is a "mental disposition-a way of being in the classroom and school" (p. 1). This type of dynamic moves not only from an insider view of schools and classrooms, but also towards a knowledge democracy in which all stakeholders work together to discover, learn and understand (Pine). Participatory action research within an educational institution recognizes that teachers are in a position of power and privilege, and that our society as a whole values knowledge as power. But a PAR research process calls for the teacher to come down from their "expert" mantle in order to adopt the curiosity which all stakeholders bring to the project (Pine). And while it is understood that teachers play a central role in the development of knowledge, PAR lessens the traditional knowledge hierarchy by advocating that all stakeholders bring knowledge and experience to the research process (Pine). Solomon and Flores (2001) alluded to this when they stated the collaborative researcher needs to be open to trusting their co-researchers. Based on this trust, the researcher becomes open to the unknown which will be discovered during the research process. Rather than controlling the research, the collaborative researcher understands and is open to moving beyond what one does know, to the realm of understanding what one does not know, to a place of learning which advocates one does not even know what they do not know (Solomon \& Flores). This type of awareness is not only very humbling and freeing for the teacher, but also 
respects the PAR research process and ensures everyone's voice is truly heard. Maguire (1987) referred to this type of co-learning when she stated that PAR advocates for a philosophy which is not based on the premise of: they know, I don't know, or they do not know, I know, but rather on the fact that we both know some things, neither knows everything.

Besides creating new knowledge, PAR initiatives can assist schools and their constituents in advancing change (Pine, 2009). Schools can become centers for change rather than targets for change (Pine). While results from any research project are hopefully of benefit to relevant stakeholders, students and teachers involved in a PAR project gain just as much from the actual research process itself as they do from the research results (Pine). This is consistent with PAR literature which states a PAR project is cyclical and not static nor linear in nature, and emphasizes the research process as much as the research results (BrintonLykes \& Hershberg, 2012; Noffke \& Somehk, 2011; Sagor, 1992). A PAR project assists participants and stakeholders by virtue of their participation in the research process. Involvement in a PAR project assists students and teachers in articulating emerging problems and issues of concern, and to identify processes to find solutions (Pine).

\section{Benefits to Students and Teachers}

Students who are involved in their learning exhibit optimism, curiosity, enthusiasm and interest (Downes \& Groundwater-Smith, 1999). Students often have an experimental view of research in that they ask questions about a group of people (McNicoll, 1999). However, a PAR initiative forces students to take this view further by asking what it feels like to be in a certain group in the first place (McNicoll). Students often do not understand the difference between traditional research and action-oriented research (McNicoll). Students often do not understand the action component imbedded within PAR, and they see PAR is simply another research method of acquiring knowledge (McNicoll). But Streck (2014) argues that PAR research not only recommends changes based on the results of research, but also provides learning due to changes and new knowledge created during the research process. Therefore, a PAR initiative can be a wonderful opportunity for students and teachers to expand their knowledge and experience related to research. As Kindon, Pain, and Kesby (2007) state, participants' capabilities, skills, and knowledge are developed during the research process.

Bell Hooks (1984) discusses the issue of power within traditional educational environments, and states it is not reasonable to suggest that power is not present within these environments. She states that power discrepancies do exist between teacher and student for the sheer reason that the teacher is tasked with assigning a grade to their student(s). Rather than pretend this power discrepancy does not exist, Hooks advocates for an acknowledgment of this power dynamic, but also suggests one use this power in non-coercive ways to enhance the learning process. McNicoll (1999) refers to this as a process within PAR which involves more than simply teaching content and grading students, it involves modeling, discussion, feedback, and collaboration, which are processes that all greatly enhance the learning process. Just as teachers need to take responsibility for the decisions they make in their practice, researchers also need to take responsibility for their decisions, rather than attempting to deny the power one has as a teacher or researcher (Koch \& Kralik, 2006). Therefore, it is important that a PAR researcher is cognisant of their judgements and expectations about the level of participation for participants and how these could result in an imbalance of power between research stakeholders (Koch \& Krilik). Brydon-Miller and Maguire (2009) remind us that PAR initiatives do allow students and teachers the opportunity to examine issues of inequality in educational environments. And finally, Kindon, Pain, and Kesby (2007) state that a PAR project can reduce hierarchical scaling of events, and offer processes to proceed in a practical and political manner.

These power inequities which exist between student and teacher are reflected in everyday life for students, therefore, it is important to examine these relationships to develop solutions to specific problems (Brydon-Miller \& Maguire, 2009). Teachers must examine how they can use their position of power within education on behalf of their students (Brydon-Miller \& Maguire). Knowledge is power (Pine, 2009; Reason \& Bradbury, 2001), and this fact is even more apparent within an educational setting in which the teacher is often viewed as someone with more knowledge (power) than students. Maguire (1987) stated the core issue for PAR is power.

A PAR initiative can change both students and teachers, and also change their perceptions of each other (Brydon-Miller and Maguire, 2009). Savin-Baden and Wimpenny (2007) state a PAR project is tasked with producing knowledge and action which is directly beneficial to a community, and is empowering through its value of consciousness-raising. Maguire (1987) contends one of the purposes of PAR is the transformation of traditional structures and relationships. A PAR initiative allows the teacher to become more collaborative, participatory, and democratizing in ways which fully engage students (Brydon-Miller \& Maguire, 2009). 


\section{Conclusion}

This paper has explained the tenets, ontology and epistemology of participatory action research. It has also described the use of PAR within the field of education. This paper has discussed the need for a decrease in power between student and teacher and inherent within this decrease in power and hierarchy, is the belief that research and teaching are both concerned with learning (Richardson, 1999). Therefore the opportunity for students and teachers to be involved in a PAR project affords enhanced collaborative learning for both in a variety of areas while co-existing in a more collaborative, non-hierarchical relationship.

Knowing and learning is situated within social, historical, cultural, and personal settings. Therefore, in order to move away from the 'banking' concept of education (Freire, 2005), and to view knowing as more than simply an intellectual endeavour, but as something that is inhabited and enacted; a way of making, thinking, and acting; a way of being (Dall'Alba \& Barnacle, 2007), participatory action research is extremely useful as provides such a process and experience for students and teachers. Education is not simply helping someone to know something, but it is also helping that person become someone (Dall'Alba). Dewey (1997) stated the purpose of education is to destroy past accumulated and self-perpetuating prejudices, and also, that the teacher has more to learn than to teach. And finally, if education is seen as a place where one of the goals is to add to the personal growth of students, one of the ways to accomplish this is for teachers to let go the need to control and dominate (Hooks, 1993). All of these aims can be achieved through the adoption of participatory action research projects involving students in the entire research process.

\section{References}

Baldwin, M. (2012). Participatory action research. In M. Grey, J. Midgley, \& S.A. Webb. (Eds.), The sage handbook of social work. (pp.467-482). London: Sage Publications Ltd. http://dx.doi.org/10.4135/9781446247648.n31

Baum, F., MacDougall, C., \& Smith, D. (2006). Participatory action research. Journal of Epidemiol Community Health, 60, 854-857. http://dx.doi.org/10.1136/jech.2004.028662

Bergold, J., \& Thomas, S. (2012). Participatory research methods: A methodological approach in motion. Forum: Qualitative Social Research, 13(4), 191-222.

Borg, M., Karisson, B., Kim, H., \& McCormack, B. (2012). Opening up for many voices in knowledge construction. Forum: Qualitative Social Research, 13(1), Art 1, 191-222.

BrintonLykes, M., \& Hershberg, R.M. (2012). Participatory action research and feminisms: Social inequalities and transformative praxis. In S.N. Hesse-Biber. (Ed.), Handbook of feminist research: Theory and praxis. (Ch 16).

Bryden-Miller, M., Maguire, P., \& McIntyre, A. (2004). (Eds.). Travelling companions: Feminism, teaching and action research. Westport, CT: Praeger.

Brydon-Miller, M., \& Maguire, P. (2009). Participatory action research: contributions to the development of practitioner inquiry in education. Educational Action Research, 17(1), 79-93. http://dx.doi.org/10.1080/09650790802667469

Brydon-Miller, M., Kral, M., Maguire, P., Noffke, S., \& Sabhlok, A. (2011). Jazz and the banyan tree. In. N.K. Denzin \& Y.S. Lincoln (Eds.), The sage handbook of qualitative research (4th ed.). (pp.387-400). Los Angeles: Sage Publications Inc.

Bywater, K. (2014). Investigating the benefits of participatory action research for environmental education. Policy Futures in Education, 12(7), 920. http://dx.doi.org/10.2304/pfie.2014.12.7.920

Calhoun, C., \& Karaganis, J. (2001). Critical theory. In G. Ritzer \& B. Smart (Eds.), Handbook of social theory (pp. 179-200). London: Sage. http://dx.doi.org/10.4135/9781848608351.n15

Cook, T. (2012). Where participatory approaches meet pragmatism in funded (health) research: The challenge of finding meaningful spaces. Forum: Qualitative social Research, 13(1).

Corey, S. (1953). Action research to improve school practices. New York: Teachers college Press.

Dahl, K. K. B. (2014). 'From worse to better': How kenyan student-teachers can use participatory action research in health education. Educational Action Research, 22(2), 159-177. http://dx.doi.org/10.1080/09650792.2013.859089

Dall'Alba, G., \& Barnacle, R. (1007). An ontological turn for higher education. Studies in Higher Education, 32(6), 
679-691. http://dx.doi.org/10.1080/03075070701685130

Dewey, J. (1938). Experience and education. New York, NY: Touchstone.

Dewey, J. (1997). How we think. Mineola, New York: Dover Publications, Inc.

Downes, T., \& Groundwater-Smith, S. (1999). Students: From informants to co-researchers. Refereed Paper, Australian Association for Research in Education, Annual Conference, Melbourne.

Fals-Borda, O. (2001). Participatory (action) research in social theory: Origins and challenges. In P. Reason \& H. Bradbury (Eds.), Handbook of action research (pp. 27-37). Thousand Oaks, CA: Sage.

Feldman, A. (2007). Teachers, Responsibility and Action Research. Educational Action Research, 15(2), 239-252. http://dx.doi.org/10.1080/09650790701314809

Freire, P. (2005). Pedagogy of the oppressed. New York: The Continuum International Publishing Group Inc.

Gaventa, J., \& Cornwall, A. (2001). Power and knowledge. In P. Reason \& H. Bradbury (Eds.), Handbook of action research (pp. 70-80). Thousand Oaks, CA: Sage.

Greenwood, D.J., \& Levin, M. (1998). Introduction to action research. Social research for social change. Thousand Oaks: Sage Publications.

Gustavsen, B. (1992). Dialogue and development. Assen-Maastricht: Van Gorcum.

Hall, B.L. (1975). Participatory research: an approach for change. Convergence, 8(2), 24-32.

Heron, J., \& Reason, P. (2001). The practice of cooperative inquiry: Research 'with' rather than 'on; people. In P. Reason \& H. Bradbury. (Eds.), Handbook of action and research. Participative inquiry and practice. (pp. 179-188). London: Sage.

Herr, K., \& Anderson, G.L. (2015). The action research dissertation. A guide for students and faculty. Los Angeles: Sage Publications Inc.

Hodgkinson, H. L. (1957). Action research-a critique. Journal of Educational Sociology, 31, 137-153. http://dx.doi.org/10.2307/2264741

Hooks, B. (1984). Feminist theory: from margin to center. Boston: South End Press.

Hooks, B. (1993). Sister of the yam. Black women and self-recovery. Boston: South End Press.

Hooks, B. (1994). Teaching to transgress: Education as a practice of freedom. New York: Routledge.

John, M. (1996). Voicing: Research and practice with the Silenced. In M. John (Ed.), Children in charge: The child is right to a fair hearing. (pp. 3-24). London: Jessica Kingsley Publishing.

Kidd, S.A., \& Kral, M.J. (2005). Practicing participatory action research. Journal of Counseling Psychology, 52(2), 187-195. http://dx.doi.org/10.1037/0022-0167.52.2.187

Kindon, S., Pain, R., \& Kesby, M. (Eds.) (2007). Participatory action research approaches and methods. Connecting people, participation and place. London: Routledge, Taylor \& Francis Group.

Koch, T., \& Kralik, D. (2006). Participatory action research in health care. Malden, MA: Blackwell Publishing.

MacDonald, S. (2003). Answering questions and asking more: Reflections on feminist participatory research. Resources for Feminist Research, 30(1/2), 77-100.

Maguire, P. (1987). Doing participatory research: A feminist approach. Amherst, MA: Center for International Education, University of Massachusetts.

McNicoll, P. (1999). Issues in teaching participatory action research. Journal of Social Work Education, 35(1), 51-62.

Minkler, M. (2000). Using participatory action research to build healthy communities. Public Health Reports, 115(2/3), 191-197. http://dx.doi.org/10.1093/phr/115.2.191

Noffke, S., \& Somekh, B. (2011). Action research. In. B. Somekh \& C. Lewin. (Eds.), Theory and methods in social research (2nd ed.). (pp. 94-101). Los Angeles: Sage Publications Inc.

Ozanne, J.L., \& Saatcioglu, B. (2008). Participatory action research. Journal of Consumer Research, 35(3), 423-439. http://dx.doi.org/10.1086/586911

Palmer, P.J. (2007). The courage of teach. Exploring the inner landscape of a teacher's life. San Francisco, CA: John 
Wiley \& Sons Inc.

Pavlish, C.P., \& Pharris, M.D. (2012). Community-based collaborative action research: A nursing approach. Sudbury, MA: Jones \& Bartlett Learning.

Pine, G.J. (2009). Teacher action research: Building knowledge democracies. Thousand Oaks, California: Sage Publications, Inc.

Reason, P., \& Bradbury, H. (2001). Introduction: Inquiry and participation in search of a world worthy of human aspiration. In P. Reason \& H. Bradbury (Eds.). Handbook of action research. Participative inquiry and practice. (pp. 1-14). Thousand Oaks, CA: Sage. http://dx.doi.org/10.1016/b978-075065398-5/50002-9

Reason, P., \& Bradbury, H. (2008). (Eds.). The sage handbook of action research: Participative inquiry and practice. London: Sage.

Richardson, C. (1999). Batos, bolillos, pochos, and pelados: Class and culture on the South Texas border. Austin: University of Texas Press.

Sagor, R. (1992). How to conduct collaborative action research. Alexandria, VA: Association for Supervision and Curriculum Development.

Savin-Baden, M., \& Wimpenny, K. (2007). Exploring and implementing participatory action research. Journal of Geography in Higher Education, 31(2), 331-343. http://dx.doi.org/10.1080/03098260601065136

Schaefer, R. I. (1967). The school as a center of inquiry. New York: Harper \& Row.

Solomon, R.C., \& Flores, F. (2001). Building trust in business, politics, relationships, and life. New York: Oxford University Press.

Streck, D. R. (2014). Knowledge and transformative social action: The encounter of selected traditions of participatory (action) research. Globalisation, Societies and Education, 12(4), 457-473. http://dx.doi.org/10.1080/14767724.2014.901907

Streubert, H.J., \& Carpenter, D.R. (2011). Qualitative research in nursing. Advancing the humanistic imperative (5th ed.). Philadelphia: Lippincott, Williams, \& Wilkins.

Susman, G. I., \& Evered, R. D. (1978). An assessment of the scientific merits of action research. Administrative Science Quarterly, 23, 582-603. http://dx.doi.org/10.2307/2392581

Tarnas, R. (1991). The passion of the Western mind. New York: Ballantine Books.

Whyte, W. F. (1991). Participatory action research. London: Sage.

Young, L.E. (2013). Participatory action research. A new science for nursing? In C.T. Beck. (Ed.), Routledge international handbook of qualitative nursing research. (pp.319-330). London: Routledge. 